\title{
PENGARUH ORIENTASI KEWIRAUSAHAAN TERHADAP KINERJA PERUSAHAAN KECIL
}

\author{
Imma Andiningtyas R.S. ${ }^{1}$ \& Ratna L. Nugroho ${ }^{2}$ \\ E-Mail: imma ars@yahoo.com
}

\begin{abstract}
ABSTRAK
Program Kemitraan adalah program untuk meningkatkan kemampuan usaha kecil agar menjadi tangguh dan mandiri melalui pemanfaatan dana dari bagian laba BUMN. PT. Telkom sebagai salah satu BUMN dalam pelaksanaan program kemitraan, membentuk suatu unit yang bernama Telkom Community Development Center (Telkom CDC), yang dimana usaha kecil yang mendapatkan pinjaman dari Program Kemitraan tersebut disebut mitra binaan Telkom CDC.

Penelitian ini menggunakan metode deskriptif dan analisis jalur (path analysis). Data diperoleh dengan cara menyebarkan kuesioner kepada 50 Mitra Binaan Telkom yang masih aktif berdasarkan Direktori UMK (Usaha Mikro Kecil) Mitra Binaan Telkom 2012. Hasil penelitian menunjukkan bahwa strategi diferensiasi pemasaran memoderasi pengaruh orientasi kewirausahaan terhadap kinerja perusahaan secara signifikan, dengan total pengaruh sebesar sebesar $32,2 \%$.
\end{abstract}

Kata Kunci: Orientasi Kewirausahaan, Lingkungan, Strategi, Kinerja Perusahaan, Usaha Kecil Mikro, Mitra Binaan Telkom

\section{PENDAHULUAN}

Pentingnya kewirausahaan dalam manajemen strategis perusahaan telah diakui secara luas dalam literatur strategi, karena akan berimplikasi kinerja proses manajemen, keputusan, dan tindakan di tingkat perusahaan (Lumpkin dan Dess: 1996). Orientasi kewirausahaan (entrepreneurial orientation) adalah unsur kunci bagi keberhasilan organisasi.

Orientasi kewirausahaan menurut Child dalam Lumpkin dan Dess (1996: 136) didefinisikan sebagai berikut:

An EO (Entrepreneurial Orientation) refers to the processes, practices, and decision-making activities that lead to new entry........... It involves the intentions and actions of key players functioning in a dynamic generative process aimed at new-venture creation.

Berdasarkan definisi tersebut dapat dipahami bahwa orientasi kewirausahaan adalah proses, praktik dan rangkaian aktivitas pembuatan keputusan untuk menghasilkan terobosan baru. Maka, diperlukan tindakan dari pemain kunci (key player) dalam proses yang dinamis untuk menciptakan usaha baru.

Kondisi yang terjadi saat ini, jumlah usaha kecil dan menengah di indonesia sedang mengalami peningkatan tiap tahunnya. Kenaikan peran Usaha Kecil dan Mikro (UKM) ditunjukkan

\footnotetext{
Universitas Telkom

Dosen Tetap Prodi MBTI Universitas Telkom
} 
oleh jumlah unit usaha dan pengusaha, serta sumbangannya terhadap penyediaan lapangan kerja Produk Domestik Bruto (PDB) dan ekspor nonmigas, dimana hal ini tentunya bermuara pada

JURNAL MANAJEMEN INDONESIA

Vol. 14 - No. 1 April 2014 peningkatan pendapatan nasional (Kementrian Koperasi dan Usaha Kecil dan Menengah, 2013).

Adanya peningkatan jumlah usaha kecil yang cukup besar tersebut, ternyata masih jauh tertinggal dibandingkan perusahaan skala besar, hal ini terlihat perolehan nilai tambah produk UKM hanya mencapai 3,40\%, jauh lebih rendah dibanding perusahaan skala besar yang mencapai 96,50 \% (Kementrian Luar Negeri RI, 2013). Hal ini diakibatan karena kurang meratanya kualitas usaha kecil, dan salah satu penyebabnya adalah kredit macet. Kredit macet tersebut menandakan adanya UKM yang tidak lancar dalam melakukan pembiyaannya. Sesuai dengan definisi dalam Tampubolon (2004:271) yang mengemukakan bahwa kredit macet (loss) mencerminkan suatu keadaan dimana penerima pinjaman (debitur), tidak mempunyai kemampuan melunasi pinjamannya. Kredit pada debitur ini sudah tidak dapat diharapkan lagi untuk ditagih.

Salah satu solusi dari kurangnya kualitas yang dihasilkan oleh usaha kecil tersebut, dibentuklah program Kemitraan yang dilakukan oleh perusahaan BUMN, sesuai dengan aturan pemerintah melalui Keputusan Menteri Negara Badan Usaha Milik Negara (BUMN) tertanggal 17 Juni 2003 No.KEP-236/MBU/2003 yang telah diubah dengan Permen No.05/MBU/2007 tentang Program Kemitraan BUMN dengan Usaha Kecil dan Program Bina Lingkungan, menginstruksikan kepada seluruh BUMN agar membentuk unit tersendiri yang mengelola Program Kemitraan BUMN dengan Usaha Kecil and Program Bina Lingkungan (PKBL). Program Kemitraan Badan Usaha Milik Negara Dengan Usaha Kecil yang selanjutnya disebut Program Kemitraan adalah program untuk meningkatkan kemampuan usaha kecil agar menjadi tangguh dan mandiri melalui pemanfaatan dana dari bagian laba BUMN. Sedangkan usaha kecil yang mendapatkan pinjaman dari Program Kemitraan Mitra Binaan dinamakan Mitra Binaan.

Hal serupa terjadi pada usaha kecil yang menjadi anggota Program Kemitraan BUMN PT. Telkom Datel Bandung. Adanya jumlah mitra binaan Telkom memiliki kredit macet yang besar ini menandakan pula bahwa Mitra Binaan Telkom CDC memiliki kinerja yang belum optimal. Besarnya jumlah mitra binaan yang mengalami kredit macet, akan mempengaruhi kinerja dari CSR PT. Telkom itu sendiri, dan hal ini akan menjadi tantangan tersendiri bagi unit Telkom CDC.

Untuk mengatasi tantangan, teori manajemen menyatakan bahwa pendekatan orientasi kewirausahaan dalam pembuatan keputusan, mereferensikan penerapan sebuah "entrepreneurial orientation" seperti yang dikemukakan oleh Lumpkin dan Dess (1996). Dengan mengacu pada dimensi-dimensi khusus oleh Miller sebagai berikut (Lumpkin \& Dess, 1996:139).

With regard to the specific dimensions of EO, Miller (1983) has provided a useful starting point. He suggested that an entrepreneurial firm is one that "engages in product market innovation, undertakes somewhat risky ventures, and is first to come up with 'proctive' innovations, beating competitors to the punch" (1983:771). Accordingly, he used the dimensions of "innovativeness", "risk taking", and "proactiveness" to characterize and test entrepreneurship. Numorous researchers have adopted an approach based on Miller's original conceptualization (e.g., Covin \& Slevin, 1989; Ginsberg, 1985; Morris \& Paul, 1987; Naman \& Slevin, 1993; Schafer, 1990).

Perusahaan dikatakan dapat menerapkan orientasi kewirausahaan adalah apabila perusahaan tersebut memiliki sifat seperti pertama dalam inovasi produk pasar, berani mengambil risiko, proaktif dalam melakukan inovasi. Dengan demikian, orientasi kewirausahaan adalah sebagai proses-proses, praktik-praktik dan aktivitas yang menggunakan inovasi produk, mengambil risiko, dan berusaha secara proaktif melakukan inovasi dengan tujuan untuk mengalahkan pesaing. Fokus pada dimensi inovasi, proaktif, dan pengambilan risiko digunakan untuk mengarahkan orientasi kewirausahaan perusahaan. Selain itu pula, dimensi inovasi, 
berani mengambil risiko, dan proaktif sudah banyak digunakan oleh peneliti-peneliti dalam mendefinisikan dari kegiatan/proses kewirausahaan tersebut.

Hubungan antara orientasi kewirausahaan dan kinerja didasarkan pada literatur-literatur ilmiah. Satu pesan penting dari hasil yang telah ada adalah kebutuhan untuk menggunakan variabel lingkungan dalam menguji hubungan diantara keduanya. Orientasi kewirausahaan memiliki hubungan yang kuat terhadap kinerja perusahaan ketika dikombinasikan dengan strategi dan lingkungan yang tepat. Sesuai dengan keterangan Lumpkin \& Dess (1996:144) yaitu "an EO may be more strongly associated with performance when it is combined with both the appropriate strategy and the proper environmental conditions". Lingkungan mempunyai peran yang sangat penting terhadap perusahaan. Lingkungan mewakili elemen ketidakpastian bagi organisasi yang mana dikarakteristikkan menurut Miller dalam Handoyo (2001:29) dalam dimensi-dimensi heterogenitas lingkungan (environmental heterogeneity), dinamika lingkungan (environmental dynamism) dan tidak dapat diprediksi (unpredictable). Lingkungan adalah faktor kontekstual yang mempunyai pengaruh kuat dalam strategi perusahaan.

Strategi adalah variabel penting lain yang berfungsi sebagai variabel moderat antara orientasi kewirausahaan dan kinerja, yang berfungsi untuk mengarahkan tindakan untuk mencapai tujuan bersama yaitu kinerja perusahaan. Pemilihan dan penerapan strategi adalah satu hal yang sangat penting dalam pencapaian tujuan perusahaan. Klasifikasi strategi dari Porter dalam Zimmerer \& Scarborough (2002:50) yang biasa disebut strategi generic Porter terdiri dari 3 strategi yaitu strategi differensiasi, biaya, dan fokus. Miller dalam Handoyo (2001:7) memodifikasi kerangka kerja Porter. Dalam penelitiannya, Miller mengajukan dua tipe dari diferensiasi yaitu diferensiasi pemasaran (marketing differentiation) dan diferensiasi inovatif (innovative differentiation) sebagai pengganti dimensi fokus. Dengan demikian, Miller menggunakan tiga dimensi yaitu dimensi kepemimpinan biaya (cost leadership), diferensiasi pemasaran (marketing differentiation) dan diferensiasi inovatif (innovative differentiation) sebagai dimensi strategi. Miller mengukur strategi ini tidak sebagai tipe yang absolut, tetapi sebagai dimensi-dimensi dimana perusahaan dapat dinilai tinggi atau rendah.Beberapa studi telah menunjukkan bahwa dimensi-dimensi strategi ini sesuai dan mempunyai hubungan erat.

Pada tulisan ini akan dibahas gambaran karakteristik Mitra Binaan Telkom CDC Datel Bandung, serta pengujian pengaruh orientasi kewirausahaan terhadap kinerja perusahaan kecil dengan moderasi lingkungan dan strategi.

\section{KERANGKA PEMIKIRAN}

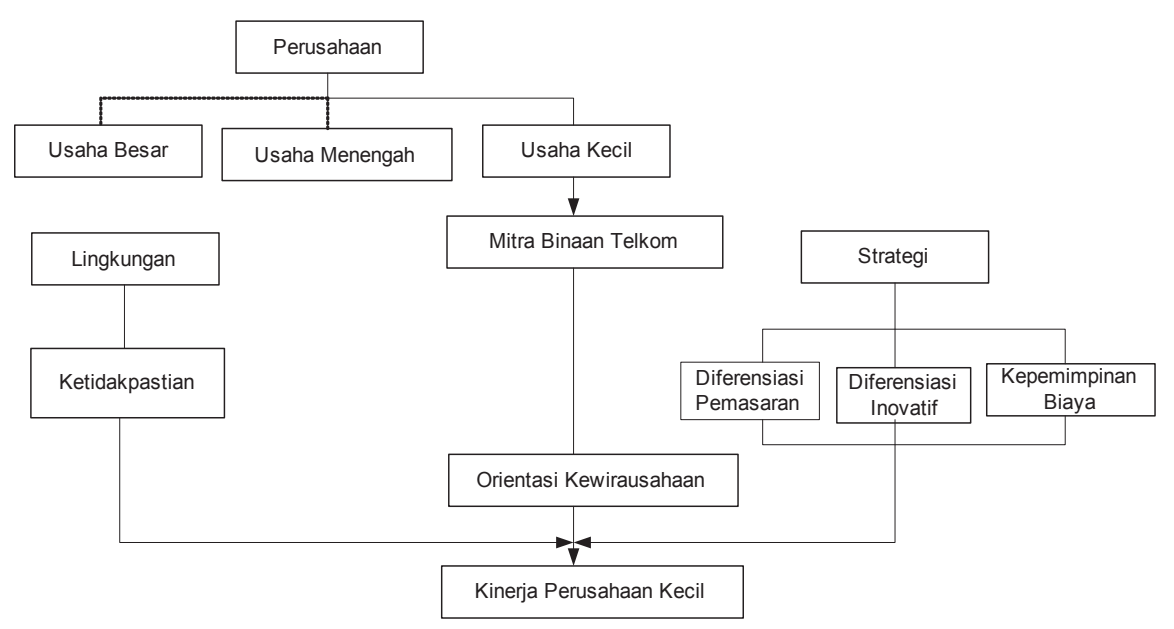

JURNAL

MANAJEMEN

INDONESIA

Vol. 14 - No. 1 April 2014
Gambar 1 Kerangka Pemikiran

\section{9}




\section{METODE PENELITIAN}

JURNAL MANAJEMEN INDONESIA

Vol. 14 - No. 1 April 2014
Dalam penelitian ini, untuk menggambarkan karakteristik Mitra Binaan Telkom CDC Datel Bandung analisis deskriptif, sedangkan untuk menguji pengaruh orientasi kewirausahaan terhadap kinerja perusahaan kecil dengan moderasi lingkungan dan strategi menggunakan analisis jalur.

Variabel yang digunakan adalah dimensi orientasi kewirausahaan yang dikemukakan oleh Miller sebagai variabel independen, kinerja perusahaan sebagai variabel dependen, serta variabel moderasi yaitu lingkungan dan strategi. Semua variabel yang digunakan, menggunakan skala ukur ordinal.

Populasi pada penelitian ini adalah mitra binaan Telkom CDC datel Bandung yang masih aktif sebagai memiliki pinjaman Telkom dan terdaftar pada Direktori UMK (Usaha Mikro Kecil) Mitra Binaan Telkom 2012. Populasi sasaran yang digunakan pada penelitian ini sebanyak 206 mitra binaan, yang terdaftar dalam Direktori UMK (Usaha Mikro Kecil) Mitra Binaan Telkom.

Teknik sampling pada penelitian ini menggunakan salah satu metode dalam sampling non probabilistik, yaitu pemilihan sampel berdasarkan kemudahan (convenience sampling). Teknik pengumpulan data yang digunakan dalam penelitian ini yaitu kuesioner (angket), dengan skala likert.

Jumlah kuesioner yang disebar adalah sebanyak 75 kuesioner sepanjang periode penelitian dengan rincian yaitu 50 kuesioner terkumpul dan sah untuk diolah, 1 responden mengisi kuesioner tidak lengkap, 15 kuesioner tidak kembali, dan 9 lainnya tidak terisi dikarenakan responden tidak bisa ditemui. Sehingga responden yang akan diteliti dalam penelitian ini adalah sebanyak 50 mitra binaan Telkom.

\section{HASIL PENELITIAN}

\section{Karakteristik Responden}

Gambaran karakteristik individu Mitra Binaan Telkom CDC Datel Bandung dari 50 kuesioner disebar, mengenai tingkat pendidikan adalah sebanyak 20 responden (40\%) berpendidikan Strata-1, 13 responden (26\%) berpendidikan SMA, 10 responden (20\%) berpendidikan Diploma, sedangkan sisanya 4 responden (8\%) berpendidikan SD, dan 3 responden (6\%) berpendidikan SMP. Hal ini menandakan bahwa mitra binaan Telkom didominasi oleh pengusaha berpendidikan formal S1, yang dimana Pendidikan Strata-1 memiliki penguasaan ilmu pengetahuan, teknologi, dan/atau kesenian. Terdapatnya penguasaan ilmu yang dimiliki oleh para pelaku usaha ini cenderung akan mencari cara bagaimana untuk menguasai penerapan orientasi kewirausahaan dalam pengambilan keputusan serta pengelolaan kewirausahaannya dengan baik.

Berdasarkan jenis kelamin, sebanyak 25 responden (50\%) adalah pria sebanyak 25 responden (50\%). Hal ini menandakan bahwa tidak ada perbedaan dari sisi jenis kelamin dalam melaksanakan kewirausahaan. Dewasa ini, tidak hanya pria yang menjadi tumpuan roda perekonomian bagi keluarga, wanita pun ikut berbisnis untuk mendatangkan tambahan penghasilan setiap bulannya.

Berdasarkan kategori umur, sebanyak 34 responden (68\%) adalah dikategorikan memasuki dewasa madya, sebanyak 11 responden (22\%) adalah dikategorikan memasuki dewasa awal, dan 5 responden (10\%) adalah dikategorikan memasuki dewasa akhir. Para pelaku Mitra Binaan Telkom CDC memiki rata-rata kategori usia dewasa madya, hal ini sesuai dikarenakan pada usia ini adalah masa-masa produktif seseorang dalam pengembangan karirnya. 
Gambaran karakteristik usaha Mitra Binaan Telkom CDC Datel Bandung dari 50 kuesioner disebar, mengenai sektor usaha adalah sebanyak 24 responden (48\%) adalah sektor usaha perdagangan, sebanyak 20 responden (40\%) adalah sektor usaha jasa, dan sebanyak 6 responden (12\%) adalah sektor usaha industri. Karakteristik usaha sebagian besar responden bergerak di bidang perdagangan (48\%) sesuai dengan kondisi Bandung yang saat ini memiliki daya saing paling kompetitif dibandingkan kota-kota lainnya, serta memiliki tujuh kawasan sentra industri perdagangan yang tersebar di Binongjati, Cigondewah, Cihampelas, Suci, Cibaduyut, Cibuntu, dan Sukamulya (Dinas Komunikasi dan Informatika, 2012).

Berdasarkan besarnya pinjaman yang diterima dari Telkom CDC adalah sebanyak 26 responden (52\%) menerima pinjaman sebesar dibawah Rp. 20,00 juta, sebanyak 12 responden (24\%) menerima pinjaman sebesar antara Rp. 20,00 juta hingga Rp. 40,00 juta, dan sebanyak 12 responden (24\%) adalah menerima pinjaman sebesar diatas Rp. 40,00 juta. sebanyak 13 Mitra Binaan (26\%) berusia kurang dari 5 tahun, 16 Mitra Binaan (32\%) berusia 5 hingga 10 tahun, 8 Mitra Binaan (16\%) berusia 10-15 tahun, 13 Mitra Binaan (26\%) berusia lebih dari 15 tahun. Besarnya pinjaman oleh Mitra Binaan Telkom didominasi oleh pinjaman sebesar dibawah Rp. 20,00 juta, hal ini sesuai dengan banyaknya kemampuan usaha kecil saat ini yang masih lemah dalam mengakses modal, sehingga jumlah pinjaman yang diterima pun kecil.

\section{Deskripsi Variabel Orientasi Kewirausahaan}

Berdasarkan hasil penelitian didapatkan informasi bahwa secara keseluruhan penerapan orientasi kewirausahaan Mitra Binaan Telkom CDC dinilai Tinggi oleh responden, dengan skor total item rata-rata 3193 atau sebesar 75,13\%. Sehingga dapat disimpulkan bahwa Mitra Binaan Telkom CDC menggunakan dengan baik elemen inovasi, proaktif, dan pengambilan risiko dalam proses, praktik dan aktivitas pembuatan keputusan yang mendorong terobosan baru pada perusahaan kecil mereka

\section{Deskripsi Variabel Lingkungan}

Berdasarkan hasil penelitian didapatkan informasi bahwa secara keseluruhan kondisi lingkungan yang dihadapi oleh Mitra Binaan Telkom CDC dinilai Tinggi oleh responden, dengan skor total item rata-rata 2431 atau sebesar 74,80\%. Sehingga dapat disimpulkan bahwa Mitra Binaan Telkom CDC Datel Bandung dihadapkan pada ketidakpastian yang tinggi, yang berarti pula bahwa lingkungan berada pada tingkat intensitas kompetisi yang tinggi, tidak dapat dibaca pasar, kompetisi yang sangat dahsyat dan mudahnya elemen dan kekuatan lingkungan eksternal mempengaruhi perusahaan.

\section{Deskripsi Variabel Strategi}

Berdasarkan hasil penelitian didapatkan informasi bahwa secara keseluruhan penerapan strategi diferensiasi pemasaran Mitra Binaan Telkom CDC dinilai Penting oleh responden, dengan skor total item rata-rata 587 atau sebesar $\mathbf{7 8 , 2 7 \%}$. Sehingga dapat disimpulkan bahwa Mitra Binaan Telkom CDC Datel Bandung dalam cara menawarkan maupun pelayanan produk kepada konsumen harus memiliki keunikan yang tinggi. Seperti melakukan strategi merek, strategi periklanan, serta keterhubungan jaringan antara pemasaran dan pelayanan..

Berdasarkan hasil penelitian didapatkan informasi bahwa secara keseluruhan penerapan strategi diferensiasi inovatif Mitra Binaan Telkom CDC dinilai Penting oleh responden, dengan skor total item rata-rata $\mathbf{3 8 0}$ atau sebesar 76,00\%. Sehingga dapat disimpulkan bahwa Mitra Binaan Telkom CDC Datel Bandung dalam pengembangan produk harus menerapkan kreatifitas yang tinggi. Seperti teknik pemasaran yang inovatif, membuat produk yang lebih unggul dibandingkan pesaing.
JURNAL

MANAJEMEN

INDONESIA

Vol. 14 - No. 1 April 2014 
JURNAL

MANAJEMEN

INDONESIA

Vol. 14 - No. 1

April 2014

Gambar 2

Path Diagram dengan Moderasi Lingkungan

Tabel 1 Koefisien Jalur dengan Moderasi Lingkungan

Gambar 3

Path Diagram dengan Moderasi Strategi

Diferensiasi Pema-

saran
Berdasarkan hasil penelitian didapatkan informasi bahwa secara keseluruhan penerapan strategi kepemimpinan biaya Mitra Binaan Telkom CDC dinilai Penting oleh responden, dengan skor total item rata-rata 391 atau sebesar 78,20\%. Sehingga dapat disimpulkan bahwa Mitra Binaan Telkom CDC Datel Bandung dalam upaya untuk memperoleh biaya produksi harus yang paling rendah dibandingkan pesaing mereka, dan melakukan kontrol biaya yang tinggi.

\section{Deskripsi Variabel Kinerja Perusahaan Kecil}

Berdasarkan hasil penelitian didapatkan informasi bahwa secara keseluruhan penerapan strategi diferensiasi pemasaran Mitra Binaan Telkom CDC dinilai Baik oleh responden, dengan skor total item rata-rata 523 atau sebesar 69,73\%. Sehingga dapat disimpulkan bahwa Mitra Binaan Telkom CDC Datel Bandung persepsi para pelaku usaha menilai kinerja perusahaan mereka sudah begitu baik.

\section{ANALISIS JALUR (PATH ANALYSIS)}

Secara ringkas, diagram untuk model analisis jalur ada pada Gambar 2 berikut ini.

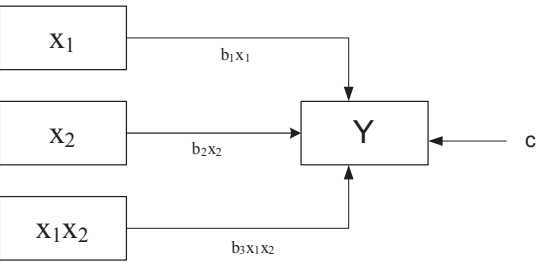

Coefficients $^{a}$

\begin{tabular}{|c|c|c|c|c|c|c|}
\hline \multirow{2}{*}{\multicolumn{2}{|c|}{ Model }} & \multicolumn{2}{|c|}{$\begin{array}{c}\text { Unstandardized } \\
\text { Coefficients }\end{array}$} & \multirow{2}{*}{$\begin{array}{c}\text { Standardized } \\
\text { Coefficients } \\
\text { Beta }\end{array}$} & \multirow[b]{2}{*}{$t$} & \multirow[b]{2}{*}{ Sig. } \\
\hline & & $B$ & Std. Error & & & \\
\hline \multirow[t]{4}{*}{1} & (Constant) & -4.938 & 6.523 & & -.757 & .453 \\
\hline & $\begin{array}{l}\text { Orientasi kewi- } \\
\text { rausahaan }\end{array}$ & .199 & .121 & .747 & 1.644 & .107 \\
\hline & Lingkungan & .202 & .164 & .638 & 1.232 & .224 \\
\hline & Interaksi X \& L & -.003 & .003 & -.744 & -.896 & .375 \\
\hline
\end{tabular}

a. Dependent Variable: Kinerja

Dari hasil perhitungan secara simultan didapatkan angka signifikansi interaksi orientasi kewirausahaan dengan lingkungan terhadap kinerja perusahaan kecil sebesar 0.375 lebih besar dari alpha 0,05. sehingga Ho dtolak dan $\mathrm{H}_{1}$ diterima.Artinya Lingkungan tidak memoderasi orientasi kewirausahaan terhadap kinerja perusahaan kecil.

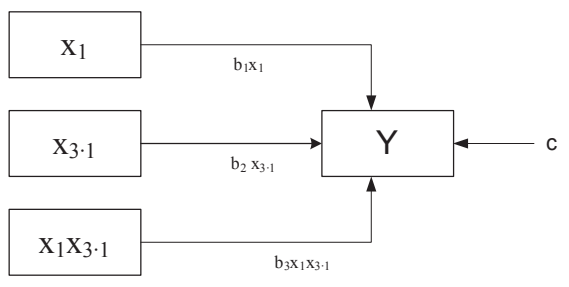


Coefficients $^{a}$

\begin{tabular}{|c|c|c|c|c|c|c|}
\hline \multirow{2}{*}{\multicolumn{2}{|c|}{ Model }} & \multicolumn{2}{|c|}{$\begin{array}{l}\text { Unstandardized Coef- } \\
\text { ficients }\end{array}$} & \multirow{2}{*}{$\begin{array}{c}\text { Standardized } \\
\text { Coefficients } \\
\text { Beta }\end{array}$} & \multirow[b]{2}{*}{$t$} & \multirow[b]{2}{*}{ Sig. } \\
\hline & & $B$ & $\begin{array}{l}\text { Std. Er- } \\
\text { ror }\end{array}$ & & & \\
\hline \multirow[t]{4}{*}{1} & (Constant) & -13.124 & 6.129 & & -2.142 & .038 \\
\hline & $\begin{array}{l}\text { Orientasi kewi- } \\
\text { rausahaan }\end{array}$ & .388 & .110 & 1.453 & 3.514 & .001 \\
\hline & $\begin{array}{l}\text { Strategi Pemasa- } \\
\text { ran }\end{array}$ & 1.617 & .673 & 1.544 & 2.404 & .020 \\
\hline & Interaksi X \& S1 & -.028 & .011 & -2.255 & -2.491 & .016 \\
\hline
\end{tabular}

a. Dependent Variable: Kinerja
JURNAL

MANAJEMEN

INDONESIA

Vol. 14 - No. 1 April 2014

Tabel 2

Koefisien Jalur dengan Moderasi Strategi Diferensiasi Pemasaran
Tabel 3

Analisis Korelasi

Simultan Moderasi Strategi Diferensiasi Pemasaran

a. Predictors: (Constant), Interaksi X \& S1, Orientasi kewirausahaan, Strategi Pemasaran

Dari hasil perhitungan secara simultan didapatkan angka signifikansi interaksi orientasi kewirausahaan dengan strategi diferensiasi pemasaran terhadap kinerja perusahaan kecil sebesar 0.016 lebih besar dari alpha 0,05 . sehingga $\mathrm{Ho}$ diterima dan $\mathrm{H}_{1}$ ditolak. Artinya strategi diferensiasi pemasaran memoderasi orientasi kewirausahaan terhadap kinerja perusahaan kecil. Besar pengaruhnya adalah $32,2 \%$.

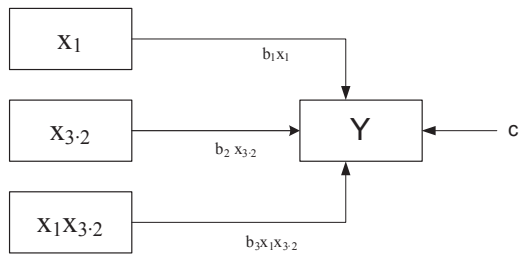

Gambar 4

Path Diagram dengan Moderasi Strategi Diferensiasi Inovatif

Coefficients $^{a}$

\begin{tabular}{|c|c|c|c|c|c|c|}
\hline \multirow{2}{*}{\multicolumn{2}{|c|}{ Model }} & \multicolumn{2}{|c|}{$\begin{array}{l}\text { Unstandardized Coef- } \\
\text { ficients }\end{array}$} & \multirow{2}{*}{$\begin{array}{c}\text { Standardized } \\
\text { Coefficients }\end{array}$} & \multirow[b]{2}{*}{$t$} & \multirow[b]{2}{*}{ Sig. } \\
\hline & & $B$ & Std. Error & & & \\
\hline \multirow[t]{4}{*}{1} & (Constant) & -5.886 & 6.583 & & -.894 & .376 \\
\hline & $\begin{array}{l}\text { Orientasi kewi- } \\
\text { rausahaan }\end{array}$ & .231 & .122 & .866 & 1.891 & .065 \\
\hline & Strategi Inovatif & 1.582 & 1.178 & .958 & 1.343 & .186 \\
\hline & Interaksi X \& S2 & -.023 & .020 & -1.151 & -1.130 & .264 \\
\hline
\end{tabular}

Tabel 4

Koefisien Jalur dengan Moderasi Strategi Diferensiasi Inovatif

\section{3}


Dari hasil perhitungan secara simultan didapatkan angka signifikansi interaksi orientasi kewirausahaan dengan strategi diferensiasi inovatif terhadap kinerja perusahaan kecil sebesar

JURNAL MANAJEMEN INDONESIA

Vol. 14 - No. 1 April 2014
0.264 lebih besar dari alpha 0,05 . sehingga $\mathrm{Ho}$ dtolak dan $\mathrm{H}_{1}$ diterima. Artinya strategi diferensiasi inovatif tidak memoderasi orientasi kewirausahaan terhadap kinerja perusahaan kecil.

\section{KESIMPULAN DAN SARAN}

\section{Kesimpulan}

Berdasarkan hasil pengolahan data dan analisis data serta pengujian hipotesis yang telah dilakukan, dapat disimpulkan hal-hal sebagai berikut

1. Ikhtisar karakteristik responden Mitra Binaan Telkom CDC Datel Bandung dalam penelitian ini adalah sebagai berikut.

a. Rata-rata tingkat pendidikan formal responden adalah Strata-1 (40,00\%), yang menandakan bahwa terdapat pendidikan yang tinggi dalam menjalankan kewirausahaan.

b. Sebanyak 25 responden (50,00\%) berjenis kelamin pria dan 25 responden $(50,00 \%)$ berjenis kelamin wanita, yang menandakan bahwa tidak terdapat perbedaan dalam jenis kelamin untuk menjalankan kewirausahaan.

c. Rata-rata usia responden berada pada kategori dewasa madya $(68,00 \%)$, yang menandakan bahwa masa usia madya memiliki produktivitas tinggi, serta memiliki kewajiban dan tanggung jawab dalam mensejahterakan keluarganya.

d. Sektor usaha responden menunjukkan sebanyak 24 responden $(48,00 \%)$ adalah sektor usaha perdagangan, sesuai dengan kondisi wilayah Bandung saat ini memiliki 7 sentra industri perdagangan.

e. Besar pinjaman responden sebanyak 26 responden (52,00\%) adalah dibawah $\mathrm{Rp}$. 20,00 juta, sebanyak 12 responden (24,00\%) adalah antara Rp. 20,00 juta hingga Rp. 40,00 juta, dan sebanyak 12 responden (24,00\%) adalah diatas Rp. 40,00 juta.

f. Umur usaha responden sebanyak 13 Mitra Binaan (26.00\%) berusia kurang dari 5 tahun, 16 Mitra Binaan (32.00\%) berusia 5 hingga 10 tahun, 8 Mitra Binaan (16.00\%) berusia 10-15 tahun, 13 Mitra Binaan (26.00\%) berusia lebih dari 15 tahun. Hal ini menandakan bahwa usaha Mitra Binaan Telkom rata-rata sedang mengalami pertumbuhan.

2. Orientasi kewirausahaan yang diterapkan oleh Mitra Binaan Telkom CDC Datel Bandung berada dalam kategori tinggi (75,3\%). Hal ini menandakan bahwa Mitra Binaan Telkom CDC menerapkan orientasi kewirausahaan dengan baik.

3. Lingkungan ketidakpastian yang dihadapi oleh Mitra Binaan Telkom CDC Datel Bandung berada dalam kategori tinggi (74,80\%). Hal ini menandakan bahwa lingkungan Mitra Binaan Telkom CDC dihadapkan pada kondisi ketidakpastian yang tinggi.

4. Strategi Diferensiasi Pemasaran yang digunakan oleh Mitra Binaan Telkom CDC berada dalam kategori kepentingan yang tinggi (78,27\%). Strategi Diferensiasi Inovatif yang digunakan oleh Mitra Binaan Telkom CDC berada dalam kategori kepentingan yang tinggi (76\%). Strategi Kepemimpinan Biaya yang digunakan oleh Mitra Binaan Telkom CDC berada dalam kategori kepentingan yang tinggi (78,20\%). Hal ini menandakan bahwa Mitra Binaan Telkom CDC beranggapan bahwa pentingnya strategi diferensiasi pemasaran, strategi diferensiasi inovatif, strategi kepemimpinan biaya diaplikasikan dalam pengembangan usaha mereka.

5. Kinerja perusahaan kecil Mitra Binaan Telkom CDC berada dalam kategori tinggi (69,73\%). Hal ini menandakan bahwa kinerja yang dihasilkan oleh Mitra Binaan Telkom CDC sudah baik.

6. Melalui uji hipotesis faktor moderasi, diperoleh hasil sebagai berikut.

a. Hasil pengujian hipotesis penelitian pertama menunjukkan bahwa interaksi antara orientasi kewirausahaan dengan kinerja perusahaan kecil tidak dipengaruhi secara 
signifikan oleh moderasi lingkungan. Artinya lingkungan tidak memperkuat atau memperlemah pengaruh orientasi kewirausahaan terhadap kinerja perusahaan kecil.

b. Hasil pengujian hipotesis penelitian kedua menunjukkan bahwa interaksi antara orientasi kewirausahaan dengan kinerja perusahaan kecil dipengaruhi secara signifikan oleh moderasi strategi diferensiasi pemasaran. Efek moderasi yang diberikan adalah negatif. Artinya strategi diferensiasi pemasaran memperlemah pengaruh orientasi kewirausahaan terhadap kinerja perusahaan kecil.

c. Hasil pengujian hipotesis penelitian ketiga menunjukkan bahwa interaksi antara orientasi kewirausahaan dengan kinerja perusahaan kecil tidak dipengaruhi secara signifikan oleh moderasi strategi diferensiasi inovatif. Artinya strategi diferensiasi inovatif tidak memperkuat atau memperlemah pengaruh orientasi kewirausahaan terhadap kinerja perusahaan kecil.

d. Hasil pengujian hipotesis penelitian ketiga menunjukkan bahwa interaksi antara orientasi kewirausahaan dengan kinerja perusahaan kecil tidak dipengaruhi secara signifikan oleh moderasi strategi kepemimpinan biaya. Artinya strategi kepemimpinan biaya tidak memperkuat atau memperlemah pengaruh orientasi kewirausahaan terhadap kinerja perusahaan kecil.

\section{Saran}

Berdasarkan kesimpulan yang diperoleh dari penelitian pengaruh orientasi kewirausahaan terhadap kinerja perusahaan kecil pada Mitra Binaan Telkom CDC maka saran yang bisa dijadikan bahan pertimbangan dan perbaikan adalah:

a. Penerapan orientasi kewirausahaan dalam berwirausaha merupakan kunci agar terjadinya kualitas kinerja usaha yang lebih baik. Oleh karena itu perlu ditingkatkan dari dimensi orientasi kewirausahaan yaitu inovasi, mengambil resiko, dan proaktif, dalam penerapan berwirausaha dari pelaku usaha itu sendiri.

b. Adanya pengaruh signifikan dari strategi diferensiasi pemasaran dalam hubungan orientasi kewirausahaan dengan kinerja usaha kecil dengan efek pengaruh yang negatif, maka usaha kecil Mitra Binaan Telkom tidak perlu menginvestasikan sumber daya-nya secara dominan pada pemasaran produk mereka, dikarenakan akan membuat kinerja usaha mereka menurun.

\section{Saran untuk Penelitian Selanjutnya}

a. Penelitian ini merupakan model untuk cakupan secara keseluruhan sektor usaha yang diberikan pinjaman Telkom CDC. Penulis menyarankan penelitian selanjutnya dapat dilakukan satu cakupan khusus sektor usaha. Hal ini diperlukan agar bisa lebih tereksplorasi dari masing-masing sektor usaha mengenai orientasi kewirausahaan, lingkungan, serta strategi yang diterapkannya.

b. Penelitian ini dilakukan pendekatan kuantitatif, maka diperlukan pendekatan lainnya seperti deskriptif, dimana terdapat uraian di dalamnya. Sehingga sikap orientasi kewirausahaan, lingkungan, dan strategi dapat lebih tereksplorasi lebih dalam lagi.

\section{DAFTAR PUSTAKA}

Community Development Center Telkom. (2012). Direktori UMK (Usaha Mikro Kecil) Mitra Binaan Telkom. Bandung: Kementrian Badan Usaha Milik Negara

Handoyo, Agus. (2001). Pengaruh Orientasi Jiwa Wirausaha Terhadap Kinerja Perusahaan Kecil dengan Lingkungan dan Strategi sebagai Variabel Moderat (Studi Kasus Pada Industri Aneka di Kota Semarang). Tesis Program Studi Magister Manajemen Universitas Dipenogoro [Online]. Tersedia : eprints.undip.ac.id/8963/. [25 Juli 2013]
JURNAL

MANAJEMEN

INDONESIA

Vol. 14 - No. 1

April 2014 
Kementrian Koperasi dan Usaha Kecil dan Menengah Republik Indonesia. (2013). GERAKAN KEWIRAUSAHAAN: Pemerintah Targetkan Wirausaha Capai 6,12 Juta Orang, [Online].

JURNAL

MANAJEMEN

INDONESIA

Vol. 14 - No. 1 April 2014
Tersedia: http://www.depkop.go.id/index.php?option=com content\&view=article\& $\mathrm{id}=1245$ :gerakan-kewirausahaan-pemerintah-targetkan-wirausaha-capai-612-jutaorang\&catid=54:bind-berita-kementerian\&ltemid=98 [5 Mei 2013]

Kementrian Luar Negeri. (2013). Menuju Komunitas Ekonomi Asean 2015: tantangan dan Peluang Bagi Kalangan Pengusaha di Jawa Barat, [Online]. Tersedia: http://www.deplu. go.id/Pages/PressRelease.aspx?IDP=1382\&l=id [5 Mei 2013]

Lumpkin, G.T. \& Dess, Gregory G. (1996). Clarifying the Entrepreneurial Orientation Construct and Linking it to Performance. The Academy of Management Review, Vol 21, No. 1, 135172 [Online]. Tersedia :. www.business.uconn.edu [14 April 2013]

Nandakumar, M.K., Ghobadian, A., \& O’Regan, N. (2010). Business-Level Strategy and Performance: The moderating effects of environment and structure. Management Decision. Vol 48 No. 6. 907-939 [Online]. Tersedia : http://www.emeraldinsight.com/ journals.htm?articleid=1864882 [30 April 2013]

Tampubolon, Robert. (2004). Risk Management : Qualitative Approach Applied to Commercial Banks. Jakarta : Elex Media Komputindo.

Zimmerer, T. W. \& Scarborough, N.M. (2002). Pengantar Kewirausahaan dan Manajemen Bisnis Kecil. Jakarta : Pearson Education Asia. 